\title{
A Comparison of the Effectiveness of Subacromial Injection and Suprascapular Nerve Block in Chronic Shoulder Pain
}

\author{
Kronik Omuz Ağrısında Subakromiyal Enjeksiyon ve Supraskapular Sinir Bloğunun \\ Etkinliğinin Karşılaştırılması \\ ๑ Gonca Sağlam, • Fatma Başak Demir*, • Berrin Hüner * * • Ömer Kuru* * \\ Erzurum Regional Training and Research Hospital, Clinic of Physical Therapy and Rehabilitation, Erzurum, Turkey \\ *Yalova Public Hospital, Clinic of Physical Therapy and Rehabilitation, Yalova, Turkey \\ **Prof. Dr. Cemil Taşçıŏlu City Hospital, Clinic of Physical Therapy and Rehabilitation, Istanbul, Turkey
}

\section{Abstract}

\begin{abstract}
Aim: Despite the frequent use of local injections for shoulder pain, previous trials revealed conflicting results. In this research, we aimed to assess and compare the efficacy of suprascapular nerve block (SNB) and subacromial steroid injection (SSI) in improving pain, quality of life, functional status and sleep quality in patients with chronic shoulder pain.
\end{abstract}

Methods: Sixty patients with chronic shoulder pain were enrolled in this study. Thirty patients received SSI and 30 underwent SNB. Initial examinations before injection and in the first week and first and third months after injection were recorded. Pain intensity levels, shoulder functions, sleep quality and quality of life were assessed at each follow-up visit using a visual analogue scale, shoulder pain and disability index, Pittsburgh sleep quality index, and the health assessment questionnaire, respectively.

Results: A statistically significant improvement was observed in terms of pain and all clinical parameters from the first week after injection in both groups, but no significant difference was observed between the groups.

Conclusion: SNB or SSI combined with exercise significantly reduces pain and increase shoulder functions, sleep and quality of life in patients with chronic shoulder pain.

Keywords: Shoulder pain, subacromial injection, suprascapular nerve block, sleep quality
Amaç: Omuz ağrısında lokal enjeksiyonlar sık kullanılmalarına rağmen önceki çalışmaların çelişkili sonuçları olmuştur. Bu çalışmada, kronik omuz ağrısında supraskapular sinir bloğu (SSB) ve subakromiyal steroid enjeksiyonun (SSE) ağrı düzeyleri, yaşam kalitesi, fonksiyonel durum ve uyku kalitesi üzerine olan etkilerini değerlendirme ve karşılaştırmayı amaçladık.

Yöntemler: Çalışmaya kronik omuz ağrısı olan 60 hasta dahil edildi. Otuz hastaya SSE, 30 hastaya SSB uygulandı. Enjeksiyon öncesi, enjeksiyon sonrası birinci hafta, birinci ve üçüncü ay muayeneleri kayıt edildi. Her kontrolde görsel analog ölçeği ile ağrı şiddeti, omuz ağrı ve disabilite ölçeği ile omuz fonksiyonları, Pittsburgh uyku kalitesi ölçeği ile uyku kaliteleri ve sağlık değerlendirme anketi ile yaşam kalitesi değerlendirildi.

Bulgular: Ağrı ve tüm klinik parametreler açısından enjeksiyon sonrası ilk hafta itibariyle iki grupta da istatistiksel olarak önemli iyileşme gözlendi, ancak iki grup arası fark izlenmedi.

Sonuç: Kronik omuz ağrısında SSB veya SSE egzersizle kombine edildiğinde önemli oranda ağrıyı azaltır, omuz fonksiyonlarını, uyku ve yaşam kalitesini arttırır.

Anahtar Sözcükler: Omuz ağrısı, subakromiyal enjeksiyon, supraskapular sinir bloğu, uyku kalitesi
Address for Correspondence/Yazışma Adresi: Gonca Sağlam, Erzurum Regional Training and Research Hospital, Clinic of Physical Therapy and Rehabilitation, Erzurum, Turkey E-mail: goncasaglam@hotmail.com ORCID: orcid.org/0000-0001-7713-4435

Received/Geliş Tarihi: 14 January 2020 Accepted/Kabul Tarihi: 21 October 2020

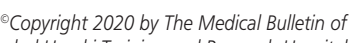
istanbul Haseki Training and Research Hospital The Medical Bulletin of Haseki published by Galenos Yayınevi. ${ }^{8}$ Telif Hakkı 2020 istanbul Haseki Eğitim ve Araştırma Hastanesi Haseki Tıp Bülteni, Galenos Yayınevi tarafından yayınlanmıştır. 


\section{Introduction}

Shoulder pain is the third most prevalent type of musculoskeletal disorder for referral to clinics after waist and neck pain and may cause functional disability and decreased quality of life, particularly at more advanced ages (1). The most common source of shoulder pain is thought to involve the extra-articular structures such as muscles, tendons and bursae. An optimal approach to shoulder pain, including adequate analgesia, is important to gain functionality and encourage rehabilitation (2). The joint complex in the shoulder and surrounding structures is one of the most common areas to which local injection therapy is applied. These methods, applied as local anesthetic and steroid combinations, are effective in pain control and functional recovery (3). Subacromial steroid injection (SSI) is a widely used therapeutic method that can be employed in the treatment of shoulder pain. Anterior, posterior or posterolateral approaches can be selected (4).

The suprascapular nerve is a peripheral nerve formed by the involvement of $\mathrm{C} 5$ and $\mathrm{C} 6$ roots that innervates the back and upper part of the shoulder joint capsule, the acromioclavicular and glenohumeral joint, the coracoclavicular ligament and the subacromial bursa (5). Suprascapular nerve block (SNB) is an alternative analgesic injection for the pain management of many shoulder pathologies $(6,7)$. It can be applied using various different techniques and the suprascapular notch is targeted where the suprascapular nerve passes below the superior transverse scapular ligament (8-10).

A small number of studies have compared these two injection techniques previously and sufficient data is not available to guide treatment for shoulder pain. In this study, we aimed to assess and compare the effects of SSI and SNB on pain, quality of life, functionality and sleep quality in patients with chronic shoulder pain.

\section{Methods}

This study was conducted with 60 patients (51 female and nine male) who required local injection therapy according to examination at the physical medicine and rehabilitation outpatient clinic. Patients with shoulder pain for three months and aged 18 or over were informed about the injection techniques. Following clinical and radiological evaluations, SSI or SNB was performed. The patients were randomized by one physician and another physician performed the injections. The exclusion criteria were as follows: having received physical therapy for the shoulder region within the past six months or local injection into the shoulder in the past three months, uncontrolled diabetes or hypertension, shoulder infection or a history of shoulder surgery, septic/tuberculous arthritis of the shoulder or anticoagulant use. Sociodemographic data including sex, age, height, body weight, chronic disease history, marital status, occupational status and education level, dominant hand, affected shoulder, duration of shoulder pain, presence of repetitive/compulsive shoulder activities and shoulder imaging results were recorded on a case report form. All patients were given a pre-injection exercise program including Codman's exercises, selfstretching exercises assisted with a stick, active range of motion (ROM) exercises, finger ladder exercises and ROM restraint.

The patients were assessed at baseline, post-injection week 1st, and month 1 st and 3rd Pain levels during sleep, rest and activity were screened based on visual analog scale (VAS) scores. Functionality was evaluated using the shoulder pain and disability index (SPADI), sleep quality using the Pittsburgh sleep quality scale (PSQI) and quality of life using the health assessment questionnaire (HAQ). Patients' baseline, first, and third month scores were recorded assuming that PSQS indicated sleep quality in the previous month. The patients did not receive any medical prescription for their pain except paracetamol or sleep disturbances during follow-ups. Informed consent was obtained from all individual participants included in this study. We state that all methods were carried out in accordance with appropriate guidelines and we also confirm that our study was approved and initiated by the Clinical Research Ethics Committee of our hospital (Prof. Dr. Cemil Taşçıŏlu City Hospital, no: 499, date: 14/06/2016).

\section{Injection Procedures}

For subacromial injection, we adopted a posterior approach, which is easier to administer and involves less risk of harm to the neurovascular structure. In this method, the patient is in a sitting position with the forelimb in flexion and internal rotation, and the physician performing the procedure is behind the patient. Under sterile conditions, the posterior side of the acromion is palpated with the thumb, and the middle finger is placed on the choroid plexus. The injection is performed $1 \mathrm{~cm}$ inferior to the posterior corner of the acromion, and $2.5 \mathrm{~cm}$ from the medulla of the humerus, acromion and choroid. A mixture of $4 \mathrm{~mL} 2 \%$ lidocaine, $5 \mathrm{~mL}$ saline $(0.9 \% \mathrm{NaCl})$ and $40 \mathrm{mg}$ methylprednisolone acetate $(1 \mathrm{~mL}$ ) (total $10 \mathrm{~mL}$ ), and a 21 Gx38 mm needle tip injector were used during injection in this study. The needle was advanced toward the anterior coracoid process and after negative aspiration, the drug mixture was administrated.

In this study, SNB was performed using the method described by Shanahan et al. (10). The block is performed with the patient sitting down and upper limbs pending beside the body. The intersection point is identified by drawing a line perpendicular to the scapula spiral from the 
inferior edge of the scapula and the injection is applied 2 $\mathrm{cm}$ lateral (in the upper-outer quadrant of the scapula) to the intersection point. The block is performed at a depth of approximately $2.5 \mathrm{~cm}$ with a $21 \mathrm{G} \times 38 \mathrm{~mm}$ needle tip. The patients in this group also received $4 \mathrm{~mL} 2 \%$ lidocaine and $40 \mathrm{mg}$ methylprednisolone acetate $(1 \mathrm{~mL})$.

\section{Statistical Analysis}

Sample size was determined by power analyses to determine the minimum number of patients to be included in our study population within 95\% confidence. Statistical analyses were performed using the IBM SPSS Statistics 22 (IBM SPSS, Turkey) software. The normal distribution fitness of the parameters was determined using the Shapiro-Wilks test. Descriptive statistics (mean, standard deviation and frequency) were used for the analyses. Quantitative data of the two groups was compared with Student's t-test and the Mann-Whitney $U$ test. ANOVA was used to determine repeated measures and the Bonferroni test to the time interval representing the source of differences. The Friedman test was used in evaluating parameters without normal distribution in the repeated measures, and the Wilcoxon Signed Ranks test was used to determine the time interval representing the source of differences. The chi-square test, Continuity (Yates) correction and Fisher's exact test were used in the analysis of qualitative data. A $p$ value of $<0.05$ was considered statistically significant.

\section{Results}

The study involved 60 patients, 51 (85\%) female and nine $(15 \%)$ male. Demographic features are shown in Table 1. The mean age of patients was $50.80 \pm 10.09$ years. The duration of shoulder pain ranged from three to 180 months, with a mean duration of $37.07 \pm 26.00$ months. There was no significant between-group difference in socio-demographic and clinical characteristics (Table 2). The mean initial VAS, HAQ or PSQI values were also not statistically different. The mean activity VAS score was decreased from $7.79 \pm 2.19$ before injection to $3.32 \pm 2.85$ at three months after SSI, and from $7.80 \pm 1.95$ before SNB to $3.23 \pm 1.94$ at three months after nerve block without a statistically significant difference. In both groups, there was also a statistically significant improvement in terms of HAQ and PSQI values at first week, first month and third month post-injections (Table 3 and 4$)(p=0.001)$. The SPADI scores in the SSI group were significantly higher at baseline and at the first week post-injection, indicating poorer functioning compared to the SNB group. However, there was a significant improvement in shoulder functions in both groups during follow-up. The initial and follow-up results are shown in Table 4.

\section{Discussion}

Chronic shoulder pain is a very common musculoskeletal condition with a high prevalence that can cause socioeconomic impairment (11). Therefore, research efforts need to be focused on obtaining more understanding about the best management of shoulder pain. SNB and SSI are injection techniques that can provide pain relief in patients who do not respond to exercise and medical treatment $(12,13)$. The success rate of SSI can range from $29 \%$ to $83 \%$, depending on factors such as injection schedule and the patient's diagnosis (14). However, the number of studies investigating the effect of SNB on rotator cuff (RC) diseases is limited. Most of these studies have involved patients with adhesive capsulitis, hemiplegic shoulder or inflammatory shoulder arthritis (15).

Overall, there are a few published studies comparing SSI with SNB in patients with chronic shoulder pain. Recently, a randomized, double-blind controlled trial in patients with RC tear demonstrated a superiority of SNB over SSI at 12 weeks (16). In this study, SSI group yielded a greater improvement in pain scores and functional status for up to 12 weeks in contrast to our findings. Similarly, Abdelshafi et al. (17) showed that SNB improves pain, disability, and ROM of the shoulders more compared to intra-articular corticosteroid injection of the shoulder and/ or physiotherapy alone. However, a metaanalysis which explored the effectiveness of SNB in the treatment of chronic shoulder revealed that SNB had similar outcomes

\begin{tabular}{|c|c|c|c|}
\hline & & Min-max ${ }^{*}$ & Mean $\pm \mathrm{SD}^{* *}$ \\
\hline \multicolumn{2}{|l|}{ Age (years) } & $27-76$ & $50.80 \pm 10.09$ \\
\hline \multirow{2}{*}{$\operatorname{Sex}(n, \%)$} & Female & 51 & 85.0 \\
\hline & Male & 9 & 15.0 \\
\hline \multicolumn{2}{|l|}{ BMI $^{\#}\left(\mathrm{~kg} / \mathrm{m}^{2}\right)$} & $17.12-50.18$ & $27.54 \pm 4.15$ \\
\hline \multirow{4}{*}{$\begin{array}{l}\text { Education } \\
\text { status }(n, \%)\end{array}$} & Not literate & 2 & 3.3 \\
\hline & $\begin{array}{l}\text { Primary school } \\
\text { graduate }\end{array}$ & 41 & 68.4 \\
\hline & $\begin{array}{l}\text { High school } \\
\text { graduate }\end{array}$ & 14 & 23.3 \\
\hline & $\begin{array}{l}\text { University } \\
\text { graduate }\end{array}$ & 3 & 5.0 \\
\hline \multirow{6}{*}{$\begin{array}{l}\text { Profession } \\
(n, \%)\end{array}$} & Public official & 3 & 5.0 \\
\hline & Manual & 8 & 13.4 \\
\hline & Retired & 5 & 8.3 \\
\hline & Self-employed & 3 & 5.0 \\
\hline & Unemployed & 2 & 3.3 \\
\hline & Housewife & 39 & 65.0 \\
\hline \multirow{2}{*}{$\begin{array}{l}\text { Marital status } \\
(n, \%)\end{array}$} & Married & 53 & 88.3 \\
\hline & Single & 7 & 11.7 \\
\hline
\end{tabular}


to intra-articular injection of the glenohumeral joints (18). Another study that compared the efficacy of SNB and local steroid injection on non-specific shoulder pain was conducted by Taskaynatan et al. (19). Patients were evaluated in terms of pain, ROM, satisfaction and disability before injection, and at one week and one month after injection. The authors concluded that both methods are effective and none is superior to each other according to follow-up parameters. Intra-articular steroid injection and SNB have also been compared in hemiplegic shoulder and adhesive capsulitis patients in various studies, with positive short-term results being obtained in terms of pain, function, disability and ROM (20-23).

\begin{tabular}{|c|c|c|c|}
\hline & & Min-max & Mean \pm SD \\
\hline \multirow{2}{*}{\multicolumn{2}{|c|}{ Shoulder pain duration (months) }} & $3-180$ & $37.07 \pm 26.00$ \\
\hline & & $n$ & $\%$ \\
\hline \multirow{2}{*}{ Affected shoulder } & Right & 43 & 71.7 \\
\hline & Left & 17 & 28.3 \\
\hline \multirow[t]{2}{*}{ Dominant hand } & Right & 51 & 85.0 \\
\hline & Left & 9 & 15.0 \\
\hline \multirow{2}{*}{$\begin{array}{l}\text { History of } \\
\text { repetitive/ } \\
\text { compulsive } \\
\text { shoulder activity }\end{array}$} & $(+)$ & 21 & 35.0 \\
\hline & $(-)$ & 39 & 65.0 \\
\hline \multirow{3}{*}{$\begin{array}{l}\text { *Previous } \\
\text { treatments } \\
\text { for shoulder } \\
\text { pathology }\end{array}$} & Medical treatment & 54 & 90.0 \\
\hline & Physical therapy & 10 & 16.7 \\
\hline & Injection & 11 & 18.3 \\
\hline \multirow{7}{*}{$\begin{array}{l}{ }^{*} \text { Comorbid } \\
\text { diseases }\end{array}$} & Comorbidity & 33 & 55 \\
\hline & Diabetes & 6 & 10 \\
\hline & Thyroid disease & 5 & 8.3 \\
\hline & Pulmonary disease & 4 & 6.7 \\
\hline & Hypertension & 15 & 25 \\
\hline & Rheumatoid arthritis & 4 & 6.7 \\
\hline & $\begin{array}{l}\text { Ankylosing } \\
\text { spondylitis }\end{array}$ & 5 & 8.3 \\
\hline \multirow{9}{*}{ MRI findings } & Impingement & 20 & 33.3 \\
\hline & $\begin{array}{l}\text { Glenohumeral } \\
\text { degeneration }\end{array}$ & 17 & 28.3 \\
\hline & $\begin{array}{l}\text { Acromioclavicular } \\
\text { degeneration }\end{array}$ & 20 & 33.3 \\
\hline & $\begin{array}{l}\text { Supraspinatus } \\
\text { tendinosis }\end{array}$ & 32 & 53.3 \\
\hline & Supraspinatus tear & 20 & 33.3 \\
\hline & $\begin{array}{l}\text { Infraspinatus } \\
\text { tendinosis }\end{array}$ & 1 & 1.7 \\
\hline & Bursitis & 11 & 18.3 \\
\hline & Effusion & 10 & 16.7 \\
\hline & Bicipital tendinitis & 5 & 8.3 \\
\hline \multicolumn{4}{|c|}{$\begin{array}{l}\text { *More than one option may apply, SD: Standard deviation, MRI: Magneti } \\
\text { resonance imaging, n: Number }\end{array}$} \\
\hline
\end{tabular}

In our study, both SSI and SNB groups experienced a decrease in VAS values from the first week to the end of the third month, and both groups exhibited similar improvement. The mean SPADI and HAQ values in our study groups were similar at baseline and third month follow-up indicating the efficacy of both injection techniques. We also observed a significant decrease in PSQI scores one and three months after injection in both groups, and the increase in sleep quality was again in agreement with the previous literature. A few previous studies have evaluated sleep quality after local shoulder injections without a comparison of SNB and SSI groups, as in our study. Shin (24) reported an increase in sleep quality and a decrease in pain levels with indirect SNB and exercise programs in patients with partial RC rupture. Rached et al. (15) and Di Lorenzo et al. (25) showed similar improvements in sleep quality after SNB.

Before initiation of this study, we performed a power analysis to achieve the required number of patients throughout the study and to obtain significant results in correlation analyses between data that increased the power of our study. The injection groups were similar in terms of almost all sociodemographic characteristics and clinical parameters prior to treatment. In addition, patient assessments and injection procedures were performed by different clinicians under equivalent circumstances for each patient. This was another strength of our study that improved the reliability of our data. Injections and patient evaluations were performed by different physicians, and frequent evaluations were carried out one week, and one and three months after injection. Another factor increasing the power of our study is that we also assessed sleep quality, which has not been investigated in previous comparison of local steroid injections.

SNB and SSI are commonly used effective interventions for chronic shoulder pain, however, considering the detrimental effects of corticosteroids on articular cartilage, SNB can be regarded as an appropriate alternative for pain relief in patients with shoulder pain.

\section{Study Limitations}

This study has several limitations. The absence of a completely untreated control group due to ethical concerns made it difficult to determine the effectiveness of injections in isolation. We also think that the exercise program had positive effects on the clinical parameters investigated. The injections were not performed on a single disease group responsible for shoulder pain. RC diseases were present in the majority of patients. Other limitations include the fact that injection was applied to anatomical points, especially in the SNB group, without ultrasound imaging. 


\begin{tabular}{|c|c|c|c|c|}
\hline \multirow{2}{*}{\multicolumn{2}{|c|}{ VAS }} & \multirow{3}{*}{$\begin{array}{l}\text { Subacromial injection group } \\
\text { Mean } \pm \text { SD (median) } \\
3.22 \pm 3.17(2)\end{array}$} & \multirow{3}{*}{$\begin{array}{l}\begin{array}{l}\text { Suprascapular nerve block } \\
\text { group }\end{array} \\
\text { Mean } \pm \text { SD (median) } \\
3.37 \pm 3.15(3.5) \\
\end{array}$} & \multirow{3}{*}{\begin{tabular}{|l|}
$1 p$ \\
0.629 \\
\end{tabular}} \\
\hline & & & & \\
\hline \multirow{5}{*}{ Rest } & Baseline & & & \\
\hline & $1^{\text {st }}$ week & $1.24 \pm 2.07(0)$ & $0.82 \pm 1.29(0)$ & 0.599 \\
\hline & 1st month & $0.84 \pm 1.66(0)$ & $0.77 \pm 1.65(0)$ & 0.754 \\
\hline & $3^{\text {rd }}$ month & $0.90 \pm 1.71(0)$ & $0.60 \pm 1.45(0)$ & 0.357 \\
\hline & $2 p$ & $p<0.001$ & $p<0.001$ & \\
\hline \multirow{5}{*}{ Activity } & Baseline & $7.79 \pm 2.19(8)$ & $7.80 \pm 1.95(8)$ & 0.755 \\
\hline & $1^{\text {st }}$ week & $4.78 \pm 2.39(5)$ & $4.00 \pm 1.97(3.5)$ & 0.124 \\
\hline & 1st month & $3.56 \pm 2.16(3)$ & $3.54 \pm 2.21(3)$ & 0.812 \\
\hline & $3^{\text {rd }}$ month & $3.32 \pm 2.85(3)$ & $3.23 \pm 1.94(3)$ & 0.981 \\
\hline & $2 p$ & $p<0.001$ & $p<0.001$ & \\
\hline \multirow{5}{*}{ Nocturnal } & Baseline & $4.77 \pm 3.19(5)$ & $5.20 \pm 3.59(5)$ & 0.823 \\
\hline & $1^{\text {st }}$ week & $2.40 \pm 3.49(0)$ & $1.60 \pm 2.44(0)$ & 0.457 \\
\hline & $1^{\text {st }}$ month & $1.90 \pm 2.87(0)$ & $1.33 \pm 1.83(0)$ & 0.771 \\
\hline & $3^{\text {rd }}$ month & $1.60 \pm 2.58(0)$ & $1.27 \pm 1.74(0)$ & 0.890 \\
\hline & $2 p$ & $p<0.001$ & $p<0.001$ & \\
\hline
\end{tabular}

\section{Table 4. Intra-group and Inter-group evaluation of HAQ, SPADI and PSQI scores}

\begin{tabular}{|c|c|c|c|c|}
\hline & & \multirow{2}{*}{$\begin{array}{l}\text { Subacromial } \\
\text { injection group }\end{array}$} & \multirow{2}{*}{$\begin{array}{l}\text { Suprascapular nerve block } \\
\text { group } \\
\text { Mean } \pm \text { SD (median) } \\
\end{array}$} & \multirow{2}{*}{$\mathbf{p}$} \\
\hline & & & & \\
\hline \multirow{5}{*}{ HAQ } & Baseline & $1.15 \pm 0.68$ & $0.94 \pm 0.67$ & 10.261 \\
\hline & $1^{\text {st }}$ week & $0.79 \pm 0.61$ & $0.57 \pm 0.37$ & 10.139 \\
\hline & 1st month & $0.55 \pm 0.39$ & $0.48 \pm 0.35$ & 10.487 \\
\hline & $3^{\text {rd }}$ month & $0.50 \pm 0.47$ & $0.45 \pm 0.37$ & 10.566 \\
\hline & ${ }^{2} p$ & $p<0.001$ & $p<0.001$ & \\
\hline \multirow{5}{*}{ SPADI } & Baseline & $65.88 \pm 21.46$ & $58.13 \pm 16.77$ & 10.042 \\
\hline & $1^{\text {st }}$ week & $40.55 \pm 24.92$ & $30.25 \pm 13.53$ & 10.051 \\
\hline & 1 st month & $29.03 \pm 20.71$ & $25.11 \pm 19.84$ & 10.426 \\
\hline & $3^{\text {rd }}$ month & $27.06 \pm 20.67$ & $22.37 \pm 10.61$ & 10.384 \\
\hline & ${ }^{2} p$ & $p<0.001$ & $p<0.001$ & \\
\hline \multirow{4}{*}{ PSQI } & Baseline & $5.87 \pm 5.37(4.5)$ & $6.63 \pm 4.68(5.5)$ & 30.295 \\
\hline & $1^{\text {st }}$ month & $4.53 \pm 4.13(4)$ & $4.73 \pm 3.08(4)$ & ${ }^{3} 0.325$ \\
\hline & $3^{\text {rd }}$ month & $4.20 \pm 3.61(4)$ & $4.53 \pm 2.64(4)$ & 30.250 \\
\hline & ${ }^{4} p$ & $p<0.001$ & $p<0.001$ & \\
\hline
\end{tabular}

\section{Conclusion}

Cortisone is a powerful anti-inflammatory that can be injected into the shoulder area to help treat a variety of shoulder conditions. SNB and SSI are practical and economical methods, with a low risk of complications, and that elicit rapid responses from the first week in the treatment of chronic shoulder pain. Since a steroid should not be injected into the same joint more than once every 3 months, SNB may be an alternative treatment for this interval.

\section{Acknowledgements}

The authors thank the patients whose participation made this study possible. 


\section{Authorship Contributions}

Surgical and Medical Practices: G.S. Concept: G.S. Design: B.H. Data Collection or Processing: G.S., F.B.D. Analysis or Interpretation: Ö.K. Literature Search: G.S. Writing: G.S.

Conflict of Interest: The authors declared no conflicts of interest.

Financial Disclosure: The authors declared that this study received no financial support.

\section{References}

1. Luime JJ, Koes BW, Hendriksen IJ, et al. Prevalence and incidence of shoulder pain in the general population; a systematic review. Scand J Rheumatol 2004;33:73-81.

2. Andrews JR. Diagnosis and treatment of chronic painful shoulder: review of nonsurgical interventions. Arthroscopy 2005;21:333-47.

3. Burbank KM, Stevenson JH, Czarnecki GR, Dorfman J. Chronic shoulder pain: Part II. Treatment. Am Fam Physician 2008;77:493-7.

4. Gruson KI, Ruchelsman DE, Zuckerman JD. Subacromial corticosteroid injections. J Shoulder Elbow Surg 2008;17(1 Suppl):118S-130S.

5. Cummins CA, Messer TM, Nuber GW. Current concepts review-suprascapular nerve entrapment. JBJS 2000;82:41524.

6. Brue S, Valentin A, Forssblad M, Werner S, Mikkelsen C, Cerulli G. Idiopathic adhesive capsulitis of the shoulder: a review. Knee Surg, Sports Traumatology, Arthrosc 2007;15:1048-54.

7. Fernandes MR, Barbosa MA, Sousa AL, Ramos GC. Suprascapular nerve block: important procedure in clinical practice. Braz J Anesthesiol 2012;62:96-104.

8. Meier $\mathrm{G}$, Bauereis $\mathrm{C}$, Maurer $\mathrm{H}$. The modified technique of continuous suprascapular nerve block. A safe technique in the treatment of shoulder pain. Anaesthesist 2002;51:74753.

9. Dangoisse MJ, Wilson DJ, Glynn CJ. MRI and clinical study of an easy and safe technique of suprascapular nerve blockage. Acta Anaesthesiol Belg 1994;45:49-54.

10. Shanahan EM, Ahern $M$, Smith $M$, Wetherall $M$, Bresnihan B, FitzGerald O. Suprascapular nerve block (using bupivacaine and methylprednisolone acetate) in chronic shoulder pain. Ann Rheum Dis 2003;62:400-6.

11. Pribicevic $M$. The epidemiology of shoulder pain: A narrative review of the literature. In: Ghosh S, editor. Pain in Perspective INTECH Open Access Publisher, 2012.

12. Grant HJ, Arthur A, Pichora DR. Evaluation of interventions for rotator cuff pathology. A systematic review. J Hand Ther 2004;17:274-99.
13. Robb G, Arroll B, Reid D, Goodyear-Smith F. Summary of an evidence-based guideline on soft tissue injuries and related disorders-Part 2: Management. J Prim Health Care 2009;1:429.

14. Osborne JD, Gowda AL, Wiater B, Wiater JM. Rotator cuff rehabilitation: current theories and practice. Phys Sportsmed 2016;44:85-92.

15. Rached RA, Rampim DB, Yamauti RH, et al. Rotator cuff syndrome: rehabilitation. Acta Fisiátrica 2013;20:96-105.

16. Coory JA, Parr AF, Wilkinson MP, Gupta A. Efficacy of suprascapular nerve block compared with subacromial injection: a randomized controlled trial in patients with rotator cuff tears. J Shoulder Elbow Surg 2019;28:430-6.

17. Abdelshafi ME, Yosry M, Elmulla AF, Al-Shahawy EA, Adou Aly M, Eliewa EA. Relief of chronic shoulder pain: a comparative study of three approaches. Middle East J Anaesthesiol 2011;21:83-92.

18. Chang KV, Hung CY, Wu WT, Han DS, Yang RS, Lin CP. Comparison of the effectiveness of suprascapular nerve block with physical therapy, placebo, and intra-articular injection in management of chronic shoulder pain: a meta-analysis of randomized controlled trials. Arch Phys Med Rehabil 2016;97:1366-80.

19. Taskaynatan MA, Yilmaz B, Ozgul A, Yazicioglu K, Kalyon TA. Suprascapular nerve block versus steroid injection for nonspecific shoulder pain. Tohoku J Exp Med 2005;205:19-25.

20. Maund E, Craig D, Suekarran S, et al. Management of frozen shoulder: a systematic review and cost-effectiveness analysis. Health Technol Assess 2012;16:1-264.

21. Jeon WH, Park GW, Jeong HJ, Sim YJ. The comparison of effects of suprascapular nerve block, intra-articular steroid injection, and a combination therapy on hemiplegic shoulder pain: pilot study. Ann Rehabil Med 2014;38:167-73.

22. Yasar E, Vural D, Safaz I, et al. Which treatment approach is better for hemiplegic shoulder pain in stroke patients: intraarticular steroid or suprascapular nerve block? A randomized controlled trial. Clin Rehabil 2011;25:60-8.

23. Tubay A, Bal S, Bayram KB, Koçyiğit H, Gürgan A. Hemiplejik Ağrılı Omuzda Supraskapular Sinir Blokajı ve Glenohumeral Eklem Enjeksiyonu: Ağrı ve Özürlülük Üzerindeki Etkilerinin Karşışşırılması. Turk J Phys Med Rehabil 2012;58:299-303.

24. Shin KM. Partial-thickness rotator cuff tears. Korean J Pain 2011;24:69-73.

25. Di Lorenzo L, Pappagallo M, Gimigliano R. Pain relief in early rehabilitaion of rotator cuff tendinitis: any role for indirect suprascapular nevre block? Eura Medicophys 2006;42:195204. 